\title{
Financing Italian Firms Throught Invoice Trading Platforms
}

\author{
Valeria Vannoni ${ }^{1}$ \\ ${ }^{1}$ Department of Economics, University of Perugia, Perugia, Italy \\ Correspondence: Valeria Vannoni, Department of Economics, University of Perugia, Perugia, Italy. Tel: \\ 039-075-585-5255. E-mail: valeria.vannoni@unipg.it
}

Received: December 9, 2019

Accepted: January 18, 2020

Online Published: February 29, 2020

doi:10.5539/ijef.v12n3p78

URL: https://doi.org/10.5539/ijef.v12n3p78

\begin{abstract}
The time lag between a business transaction and its payment has generated significant problems in the financial capacity of Italian firms over time. The development of technology applied to finance (FinTech) can offer a useful alternative to mitigate this problem; among the new different forms of financing, invoice trading is a recently developed technique that already shows positive signs of response from companies. This paper aims to make an empirical contribution by investigating the profile of Italian firms using invoice trading as a source of short-term funding, according to their demographics (sectors/geographical regions/lifecycle phase), financials (turnover, credit) and creditworthiness (acceptance/rejection of applications). The analysis, furthermore, draws on survey data collected among all invoice trading platforms active in Italy as of June, 2018. Results show that the number of applications is very high, even if it still corresponds to a limited success rate, due to the low creditworthiness profile of firms.
\end{abstract}

Keywords: firm financing, alternative finance, invoice trading

JEL codes: G23; G30.

\section{Introduction}

The long collection time of commercial receivables is a constraint that has a major impact on the liquidity of Italian small and medium enterprises (SMEs), thus limiting their investments and aggravating the sustainability of their indebtedness. Moreover, firms face binding liquidity constraints while seeking debt and equity in highly imperfect markets. To have an extimation about the average trend in the time lag between a business transaction and its payment (collection period) for Italian SMEs, we firstly consider firms with available unconsolidated financial data in Orbis database by Bureau Van Dijk. Our research strategy uses the following criteria: all active and unlisted companies satisfying the requirements of European Commission for small and medium enterprises in term of total asset, turnover and number of employees, with a known value for collection period (days) and credit period (days) for the reference year (2018), excluding banks, insurance companies and post services. We collected data for 2,498 firms. Table 1 presents the industry breakdown of firms' collection period. The most critical industries are wholesale \& retail trade and other services, which together accounts around $43 \%$ of the total. Table 2 shows descriptive statistics for these firms on main financials and collection period data. The average value for collection period (74 days) confirms the high critical issue relating to incoming cash flows for firms.

Table 1. Breakdown by industry of firms' collection period, reference year 2018

\begin{tabular}{|c|c|c|c|c|c|}
\hline Collection period (days) & Less than 2.86 & From 2.86 to 65.01 & From 65.01 to 115.78 & More than & 115.78 Total \\
\hline Primary sector & 18 & 17 & 14 & 13 & 62 \\
\hline Food, beverages, tobacco & 11 & 18 & 37 & 11 & 77 \\
\hline Textiles, wearing apparel, leather & 16 & 11 & 27 & 15 & 69 \\
\hline Wood, cork, paper & 5 & 11 & 15 & 12 & 43 \\
\hline Publishing, printing & 4 & 6 & 7 & 8 & 25 \\
\hline Chemicals, rubber, plastics, non-metallic products & 21 & 14 & 40 & 38 & 113 \\
\hline Metals \& metal products & 31 & 25 & 94 & 82 & 232 \\
\hline Machinery, equipment, furniture, recycling & 50 & 56 & 88 & 90 & 284 \\
\hline Gas, Water, Electricity & 5 & 6 & 6 & 12 & 29 \\
\hline Construction & 44 & 24 & 38 & 44 & 150 \\
\hline
\end{tabular}




\begin{tabular}{|c|c|c|c|c|c|}
\hline Wholesale \& retail trade & 141 & 166 & 131 & 133 & 571 \\
\hline Hotels \& restaurants & 78 & 80 & 5 & 0 & 163 \\
\hline Transport & 20 & 26 & 25 & 24 & 95 \\
\hline Other services & 163 & 134 & 90 & 124 & 511 \\
\hline Education, Health & 19 & 31 & 7 & 17 & $\begin{array}{c}74 \\
2,498\end{array}$ \\
\hline
\end{tabular}

Source: author's elaboration on data from Bureau Van Dijk.

Table 2. Descriptive statistics of firms, main financials, reference year 2018

\begin{tabular}{|c|c|c|c|c|c|}
\hline & Average & Median & Min & $\operatorname{Max}$ & St. dev. \\
\hline Number of employees & 19 & 12 & 1 & 216 & 3.55 \\
\hline Total Asset, th eur & 4,907 & 2,728 & 37 & 41,258 & $1,089.37$ \\
\hline Net Income, th eur & 203 & 56 & $(4,795)$ & 16,698 & 73.64 \\
\hline Cash flow, th eur & 360 & 152 & $(4,219)$ & 16,701 & 103.91 \\
\hline Loans, th eur & 403 & 10 & - & 14,770 & 196.72 \\
\hline Debtors, th eur & 1,049 & 402 & - & 24,807 & 323.05 \\
\hline Creditors, th eur & 767 & 270 & - & 14,988 & 248.52 \\
\hline Credit period, days & 51 & 41 & - & 966 & 5.16 \\
\hline Collection period, days & 74 & 65 & - & 796 & 4.25 \\
\hline
\end{tabular}

Source: author's elaboration on data from Bureau Van Dijk.

Firms could benefit from the use of new financing solutions to cope with short-term liquidity shortages and improve their financial and economic performance.

In this regard, a positive contribution to mitigate the problem could be found in digital financing.

Digital Finance encompasses a magnitude of new financial products, financial businesses, finance-related software, and novel forms of customer communication and interaction, delivered by FinTech companies and innovative financial service providers (Gomber et al., 2017).

Trading of commercial invoices is therefore the opportunity for the firm to obtain a cash advance. Invoice trading platforms offer this service through three main models: marketplace; direct purchase; supply chain finance. In the first case, the platforms put firms in contact with investors and sometimes organize a competitive auction, based on an initial listing; the auction can be opened to a category more or less extensive of accredited investors. Other portals directly purchase invoices, offering a final price to the company; normally, these are portals that have signed agreements with institutional investors and typically arrange credit securitization transactions, subscribed by these investors.

Finally, some portals focus on supply chain finance, with a key role of a large company, which offers its suppliers the opportunity to transfer the invoices to the investors accredited in the platform. In any case, the investor's remuneration will depend on the difference between the price of credit purchase and the invoice amount.

This study aims to analyze the activity of invoice trading platforms operating in Italy, according to users' (firms) characteristics. The paper is organized as follows: paragraph 1 reviews the literature on digital and fintech financing for firms; paragraph 2 is for the empirical analysis; the last section concludes by commenting main results and suggesting for further research.

\section{Literature Review}

Firm financing has established itself as a main subject of enduring academic, political and professional debate, over time.

There is a broad literature that, following the numerous studies on the capital structure of firms (Miller, 1977; Modigliani, 1982; Bradley \& Jarrell, 1984; Myers, 1984; Jensen, 1986; Rajan \& Zingales, 1995; Baker \& Wurgler, 2002; Hall et al., 2004; Fan et al., 2012), has been deepening some main related topics: financial constraints (Korajczyk \& Levy, 2003; Campello et al., 2010; Behr et al., 2013; Ferrando \& Mulier, 2015; Minetti et al., 2019); alternative financing options (Titman, 1992; Carpenter \& Peterson, 2002; Carbò-Valverde et al., 2016; Moritz et al., 2016; Chauhan \& Huseynov, 2018); firm-bank relationship (Berger \& Udell, 1995; Demirgüç-Kunt \& Levine, 2001; Albertazzi \& Marchetti, 2010; Cenni et al., 2015; Beck et al., 2017); market-oriented financing (Agarwal \& Gort, 1996; Demirgüç-Kunt \& Maksimovic, 1996; Barry \& Mihov, 2015; Lowry et al., 2017). Among these contributions, a subsequent but flourishing literature discuss the short term 
financing issue (Kallberg et al., 1982; Hill \& Sartoris, 1988; Srinivasa \& Kumar, 2011). This specif topic can be also fitted into the broader theme of working capital management of firms, that may have a consequent impact on firms survival and growth (Kargar \& Blumenthal, 1994), since the matching principle correctly predicts that the amount of short-term debt financing that a firm uses is directly related to the quantity of the firm's current assets (Fosberg, 2012).

In parallel to the emerging of new business models and technologies, and also due to the increasing difficulties in accessing traditional financing channels, academic research has begun to deal with digital financing and FinTech solutions. Studies on this topic are recent, and related issues are not yet critically addressed enough in the literature (Ozili, 2018). Today, various platforms offer digitalized services to firms in the area of factoring, invoicing, leasing, and crowdfunding (Gomber et al., 2017). The largest number of academic papers deals with crowdfunding (Belleflamme et al., 2014; Chemla \& Tinn, 2019), expecially in the equity-based form (Vismara, 2016; Vulkan et al., 2016; Walthoff-Borm et al., 2018); other contributions mainly attempt to analyze both the positive and negative impacts that alternative finance may have on users. Academics are fairly consistent in affirming that the transformative developments in the financial services industry will most likely improve and expand access of firms and individuals to finance (Ketterer, 2017). Baeck et al. (2014), through a comprehensive study on UK market, show that the innovative, technology led approach has improved access to finance for SMEs, even if the level of SMEs' awareness on this source of financing doesn't still comply with the percentages of firms accessing to the platforms to seek finance. Wales (2015) summarizes the problems and opportunities posed by alternative funding sources: reducing costs and time, with a nimble and efficient financing and accessing to market opportunities are main strengths, while risk assessment should be a critical issue.

According to the purpose of our study, we attempt to deepen literature about invoice trading, but there are still very few contributions. In online invoice trading, an invoice is generally sold to one or more investors; hence, its features are closely linked to other forms of crowdfunding. Moreover, with respect to the theoretical concept underlying the transaction, ie receivables disinvestment, invoice trading could be considered as a particular form of factoring. Klapper (2005) underlines that what is unique about factoring is that the credit provided by a lender is explicitly linked to the value of a supplier's accounts receivable and not the supplier's overall creditworthiness. She illustrates, moreover, how the use of electronic channels and a supportive legal and regulatory environment can cut costs and provide greater SME services in emerging markets. In this regard, invoice trading could be considered as an evolution of traditional (off-line) factoring. Dorfleitner et al. (2017) are the first to analyze the new market of invoice trading on web-based platforms, providing first empirical evidence about pricing in the online invoice trading market.

\section{Empirical Analysis}

\subsection{Methodology}

Considering the exploratory nature of our study, the methodological approach adopted in this analysis is broadly qualitative, using a semi-structured questionnaire, to deepen the characteristics of Italian firms applying for invoice trading financing.

The number of invoice trading platforms active in Italy as end of June 2018 is six; examining platforms' websites, we retrieved their email addresses; we sent the form for the compilation through these email addresses. The response rate is $67 \%$; the platforms that did not complete the questionnaire, however, responded to our email, informing us that they would not participate in the survey for confidentiality issues. The form consists of ten questions (Table 3).

Table 3. The questionnaire

1. Number of customers (firms) updated on the survey date

2. Turnover (average) of customers (firms), last available data

3. Number of applications from firms updated on the survey date

4. Acceptance of applications (percentage)

5. Reasons of rejection (specify)

6. Average value of credit to firms

7. Geographical distribution of applicants: indicate if the phenomenon is mainly concentrated in a region (which)

8. Sectoral distribution of applicants: indicate if the phenomenon is mainly concentrated in a sector (which)

9. Life cycle of the company: indicate whether the companies are in the maturity stage or in another phase

10. Trend of operations: indicate if there criticalities or not.

Note. Questions 1 and 3 relate to the customers' portfolio of the platforms; Questions 2, 7, 8 and 9 aim to profile firms according to their dimensional (turnover), geographic, sectoral (industry) and stage characteristics; the remaining questions deal with risk assessment. 


\subsection{Results}

Firms turning to invoice trading platforms operate mainly in the manufacturing and wholesale sectors, in their maturity stage, geographically concentrated in the north of the country (Table $4, a, b, c)$, with an average turnover of 12,875 th/euros. The average value of in advance credit is about 75 th/euros. The sectoral and geographical distribution reflects the dynamics of the Italian GDP; the use of this funding channel by mature companies is in line with the literature that has long highlighted the difficulties in accessing external financing from firms that are in other stages, in particular in the start-up phase (Berger \& Udell, 1998).

Table 4. Firms by industry, stage of business, region

a) Industry

\begin{tabular}{lr}
\hline Applicants by industry & Frequences, percentages \\
\hline Manufacture & $27.2 \%$ \\
Wholesale trade & $18.2 \%$ \\
Manufacture of fabricated metal products & $18.2 \%$ \\
Pharmaceutical industries & $9.1 \%$ \\
Energy & $9.1 \%$ \\
Transports & $9.1 \%$ \\
No prevalence & $9.1 \%$ \\
Total & $100.0 \%$ \\
\hline
\end{tabular}

b) Stage of business

\begin{tabular}{lr}
\hline Lifecycle of applicants & Frequences, percentages \\
\hline Maturity & $80.0 \%$ \\
Startup & $20.0 \%$ \\
Total & $100.0 \%$ \\
\hline
\end{tabular}

c) Geographical region

\begin{tabular}{lr}
\hline Geographical distribution of applicants & Frequences, percentages \\
\hline North & $50.0 \%$ \\
Center & $37.5 \%$ \\
South with islands & $12.5 \%$ \\
Total & $100.0 \%$ \\
\hline
\end{tabular}

Figure 1 shows that the average number of firms using invoice trading financing is approximatly 169 firms per platform; this result is affected by a platform, which records a number of customers considerably greater than the other three (260).

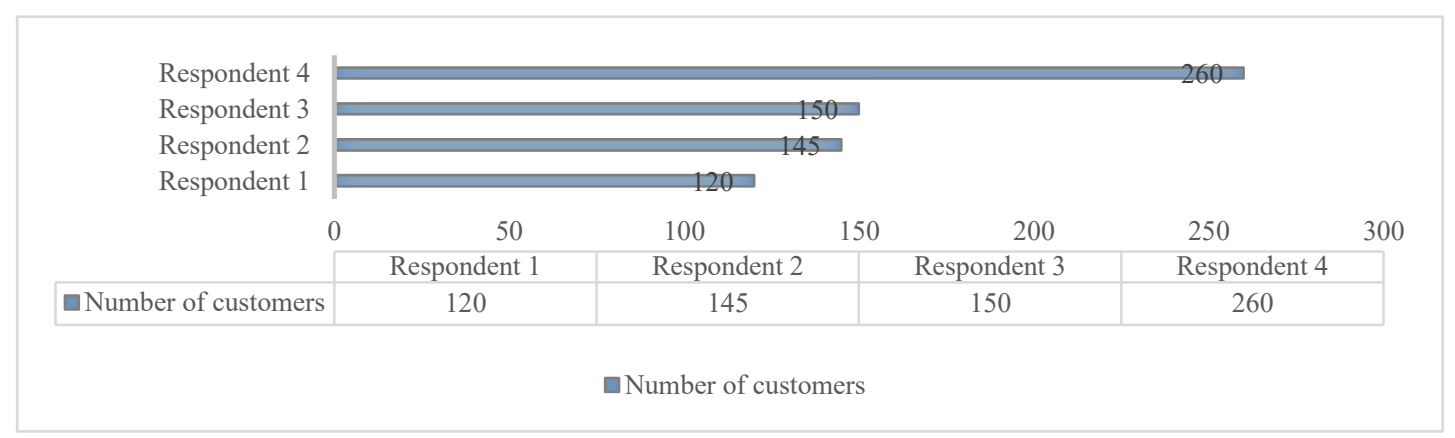

Figure 1. Number of customers

Figure 2 presents results about number of applications. The averagre number of applications is 913 , but there is a very great variance among the respondents, with a platforms significantly less relevant than the others (170). 


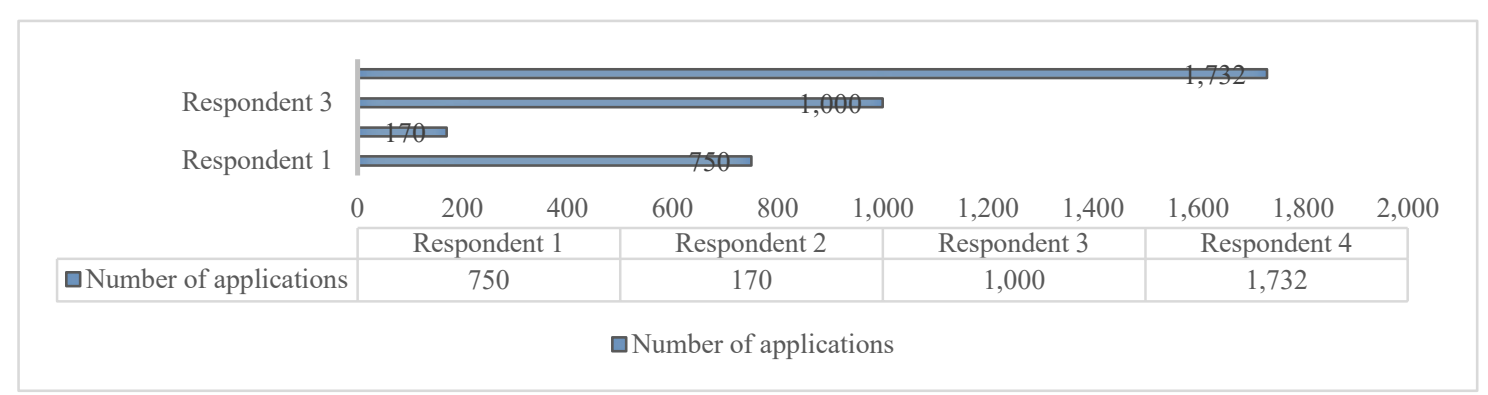

Figure 2. Number of applications

Combining the answers to questions 1 and 3 of the form, the following acceptance rates can be estimated: Respondent $1=16 \%$; Respondent $2=85 \%$; Respondent $3=15 \%$; Respondent $4=15 \%$. Our estimation is in line with the answers by respondents 1 and 4 to the specific question about acceptance rate in the form, while is quite distant from answers by respondent 2 and 3 (Figure 3).

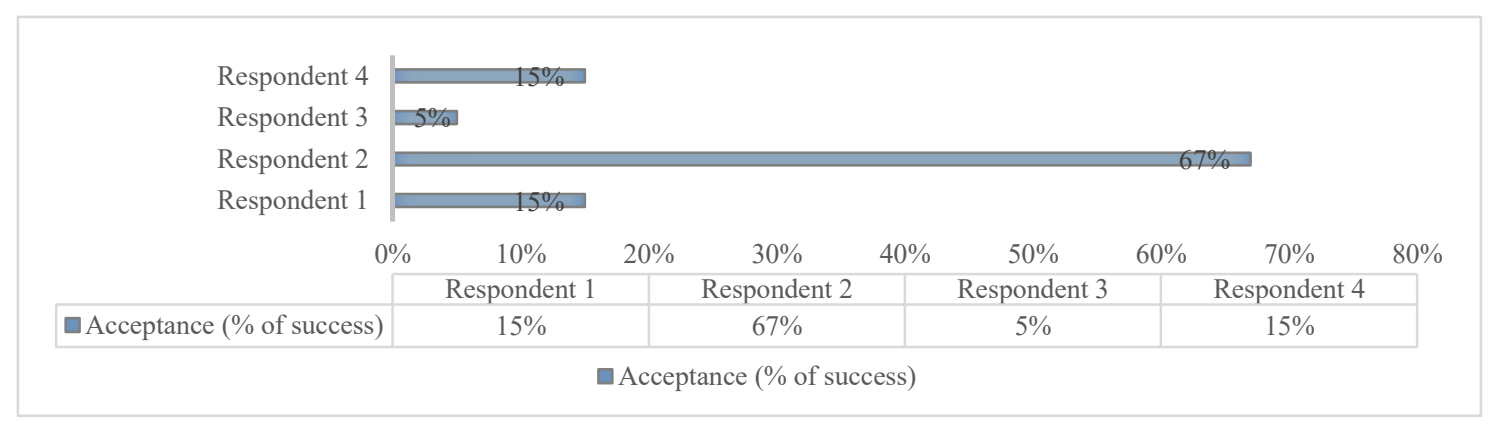

Figure 3. Acceptance of applications

The main reason of rejection is the low creditworthiness profile of firms; in general, the refusal follow the risk assessment approach traditionally associated with loan transactions (Table 5). Each platform could indicate more than one reason, so the results were firstly collected through absolute frequencies and then translated into percentages.

Table 5. Reason of rejection

\begin{tabular}{lr}
\hline Reasons of rejection & Frequences, percentages \\
\hline Creditworthiness (low) & $37.5 \%$ \\
Default risk & $12.5 \%$ \\
Fraud risk & $12.5 \%$ \\
Prejudicial information on firms and shareholders & $12.5 \%$ \\
Pricing & $12.5 \%$ \\
Invoice amount (too low) & $12.5 \%$ \\
Total & $100.0 \%$ \\
\hline
\end{tabular}

Answers to question 10 did not highlight any critical points regarding the regularity of the obligations connected to the financing operations by firms. Only one respondents underlines that $5.42 \%$ of invoices has had a serious delay in payment by debtor.

\section{Discussion and Conclusions}

Our paper proposes an analysis of the use of invoice trading as a short term financing source for Italian firms.

To the best of our knowledge there are no studies focused on this specific topic, with the exception of the report on alternative finance for firms by Politecnico di Milano (2018), which is annually updated with a paragraph on invoice trading, presenting active platforms, invoice trading mechanisms and some data about the number and the value of traded invoices. 
In our study, we adopted a qualitative approach, using a semi-structured questionnaire, distributed to all the platforms active in Italy as end of June 2018. In the author's view, the Italian case can be relevant for other countries in which firms share similar characteristics to those ones in Italy, according to their short term financing needs.

Main findings highlight a growing interest about this alternative source of financing by firms, especially in their maturity stage; moreover, reasons for rejection seem to follow the traditional crediworthiness evaluation approach. The generability of results is however limited by the fact that the study represents a first attempt to tackle the issue of invoice trading as a source of financing. Future research will contribute in this sense, widening the time of investigation; a further element to improve the research will consist in acquiring balance sheet data of the companies using invoice trading and in monitoring data about platforms' deals.

\section{References}

Agarwal, R., \& Gort, M. (1996). The evolution of markets and entry, exit and survival of firms. The Review of Economics and Statistics, 78(3), 489-498. https://doi.org/10.2307/2109796

Albertazzi, U., \& Marchetti, D. (2010). Credit Supply, Flight to Quality and Evergreening: An Analysis of Bank-firm Relationships after Lehman. Bank of Italy, Working Paper 756. https://doi.org/10.2139/ssrn.1670563

Baeck, P., Collins, L., \& Zhang, B. (2014). Understanding alternative finance: The UK alternative finance industry report.

Baker, M., \& Wurgler, J. (2002). Market Timing and Capital Structure. The Journal of Finance, 57(1), 1-32. https://doi.org/10.1111/1540-6261.00414

Barry, C. B., \& Vassil, T. (2015). Debt financing, venture capital, and the performance of initial public offerings. Journal of Banking \& Finance, 58(C), 144-165. https://doi.org/10.1016/j.jbankfin.2015.04.001

Beck, T., Degryse, H., De Haas, R., \& N. van Horen. (2014). When arm's length is too far: relationship banking over the business cycle. CESifo Working Paper Series 4877, CESifo Group Munich. https://doi.org/10.2139/ssrn.2489017

Behr, P., Norden, L., \& Noth, F. (2013). Financial constraints of private firms and bank lending behavior. Journal of Banking \& Finance, 37(9), 3472-3485. https://doi.org/10.1016/j.jbankfin.2013.05.018

Belleflamme, P., Lambert, T., \& Schwienbacher, A. (2014). Crowdfunding Tapping the Right Crowd. Journal of Business Venturing, 29, 585-609. https://doi.org/10.1016/j.jbusvent.2013.07.003

Berger, A., \& Udell, G. (1995). Relationship lending and lines of credit in small firm finance. The Journal of Business, 68(3), 351-382. https://doi.org/10.1086/296668

Berger, A., \& Udell, G. (1998). The economics of small business finance: the roles of private equity and debt markets in the financial growth cycle. Journal of Banking \& Finance, 22(6-8), 613-673. https://doi.org/10.1016/S0378-4266(98)00038-7

Bradley, M., Jarrell, G. A., \& Han, K. E. (1984). On the Existence of an Optimal Capital Structure: Theory and Evidence. The Journal of Finance, 39(3). Papers and Proceedings, Forty-Second Annual Meeting, American Finance Association, San Francisco, CA, December 28-30, 1983 (Jul., 1984), pp. 857-878. https://doi.org/10.1111/j.1540-6261.1984.tb03680.x

Campello, M., Graham, J. R., \& Harvey, C. (2010). The real effects of financial constraints: Evidence from a financial crisis. Journal of Financial Economics, 97(3), 470-487. https://doi.org/10.1016/j.jfineco.2010.02.009

Carbó-Valverde, S., Rodríguez-Fernández, F., Udell, G.F. (2016). Trade Credit, the Financial Crisis, and SME Access to Finance. Journal of Money, Credit and Banking, 48(1), 113-143. https://doi.org/10.1111/jmcb.12292

Cenni, S., Monferrà, S., Salotti, V., Sangiorgi, M., \& Torluccio, G. (2015). Credit rationing and relationship lending. Does firm size matter?. Journal of Banking \& Finance, 53, 249-265. https://doi.org/10.1016/j.jbankfin.2014.12.010

Chauhan, G. S., \& Huseynov, F. (2018). Corporate financing and target behavior: New tests and evidence. Journal of Corporate Finance, 48(C), 840-856. https://doi.org/10.1016/j.jcorpfin.2016.10.013

Chemlan, G., \& Tinn, K. (2019). Learning Through Crowdfunding. Management Science. 
Cornelli, F., Portes, R., \& Shaffer, M. E. (1996). The Capital Structure of Firms in Central and Eastern Europe. CEPR Discussion Paper No. 1392.

Demirgüç-Kunt, A., \& Maksimovic, V. (1996). Stock market development and financing choices of firms. World Bank Economic Review, 10(2), 341-369. https://doi.org/10.1093/wber/10.2.341

Demirguc-Kunt, A., Martinez Peria, M. S., \& Tressel, T. (2015). The impact of the global financial crisis on firms' capital structure. Policy Research working paper; no. WPS 7522. Washington, D.C: World Bank Group. https://doi.org/10.1596/1813-9450-7522

Fan, J. P. H., Titman, S., \& Twite, G. (2012). An international comparison of capital structure and debt maturity choices. Journal of Financial and Quantitative Analysis, 47, 23-56. https://doi.org/10.1017/S0022109011000597

Ferrando, A., \& Mulier, K. (2015). Firms' financing constraints: Do perceptions match the actual situation? The Economic and Social Review, 46(1), 87-117.

Fosberg, R. H. (2012). Capital structure and the financial crisis. Journal of Finance and Accountancy.

Gomber, P., Koch, J. A., \& Siering, M. (2017). Digital Finance and FinTech: current research and future research directions. Journal of Business Economics, 87(5), 537-580. https://doi.org/10.1007/s11573-017-0852-x

Hall, G., Hutchinson, P., \& Michaelas, N. (2004). Determinants of the capital structures of European SMEs. Journal of Business Finance and Accounting, 31, 711-728. https://doi.org/10.1111/j.0306-686X.2004.00554.x

Hill, N. C., \& Sartoris, W. L. (1988). Short-term financial management. Macmillan.

Jensen, M. (1986). Agency costs of free cash flow, corporate finance and takeovers. American Economic Review, 76, 323-339.

Kallberg, J. G., White, R. W., \& Ziemba, W. T. (1982). Short Term Financial Planning under Uncertainty. Management Science, 28, 670-682. https://doi.org/10.1287/mnsc.28.6.670

Kargar, K., \& Blumenthal, R. A. (1994). Leverage Impact of Working Capital in Small Businesses. TMA Journal., 14(6), 46-53.

Ketterer, J. A. (2017). Digital Finance: New times, new challenges, new opportunities. IDB-DP-501. https://doi.org/10.18235/0000640

Klapper, L. (2005). The Role Of Factoring For Financing Small And Medium Enterprises. Research Working Papers - The World Bank. https://doi.org/10.1596/1813-9450-3593

Korajczyk, R., \& Levy, A. (2003). Capital structure choice: macroeconomic conditions and financial constraints. Journal of Financial Economics, 68(1),75-109. https://doi.org/10.1016/S0304-405X(02)00249-0

Lowry, M., Michaely, R., \& Volkova, E. (2017). Initial Public Offer- ings: A Synthesis of the Literature and Directions for Future Research. Foundations and TrendsR in Finance, 11(3-4), 154-320. https://doi.org/10.1561/0500000050

Miller, M. H. (1977). Debt and Taxes. The Journal of Finance, 32(2). Papers and Proceedings of the Thirty-Fifth Annual Meeting of the American Finance Association, Atlantic City, New Jersey, September 16-18, 1976 (May, 1977), 261-275. https://doi.org/10.1111/j.1540-6261.1977.tb03267.x

Minetti,R., Murro, P., Rotondi, Z., \& Chun, Z. S. (2019). Financial Constraints, Firms' Supply Chains, and Internationalization. Journal of the European Economic Association, 17(2), 327-375. https://doi.org/10.1093/jeea/jvx056

Modigliani, F. (1982). Debt, Dividend Policy, Taxes, Inflation, and Market Valuation. The Journal of Finance, 37(2), 255-273. https://doi.org/10.1111/j.1540-6261.1982.tb03549.x

Moritz, A., Block, J. H., \& Heinz, A. (2016). Financing patterns of European SMEs - an empirical taxonomy. Venture Capital, 18(2), 115-148. https://doi.org/10.1080/13691066.2016.1145900

Myers, S. C. (1984). The capital structure puzzle. The Journal of Finance, 39(3), 574-592. https://doi.org/10.1111/j.1540-6261.1984.tb03646.x

Ozili, P. K. (2018). Impact of digital finance on financial inclusion and stability. Borsa Istanbul Review, 18(4), 329-340. https://doi.org/10.1016/j.bir.2017.12.003

Rajan, R. G., \& Zingales, L. (1995). What do we know about capital structure? Some evidence from 
international data, The Journal of $1421-1460$. https://doi.org/10.1111/j.1540-6261.1995.tb05184.X

Srinivasa, R. N. R., \& Mishra, V. K. (2011). Short-term financing in a cash-constrained supply chain. International Journal of Production Economics, 134(2), 407-412. https://doi.org/10.1016/j.ijpe.2009.11.014

Vismara, S. (2016). Equity retention and social network theory in equity crowdfunding. Small Business Economics, 46(4), 579-590. https://doi.org/10.1007/s11187-016-9710-4

Vulkan, N., Astebro, T., \& Fernández, S. M. (2016). Equity crowdfunding: A new phenomena. Journal of Business Venturing Insights, 5, 37-49. https://doi.org/10.1016/j.jbvi.2016.02.001

Wales, K. (2015). Internet finance: digital currencies and alternative finance liberating the capital markets. Journal of Governance and Regulation, 4(1), 190-201. https://doi.org/10.22495/jgr_v4_i4_c1_p6

Walthoff-Borm, X., Schwienbacher, A., \& Vanacker, T. (2018). Equity crowdfunding: First resort or last resort?. Journal of Business Venturing, 33(4), 513-533. https://doi.org/10.1016/j.jbusvent.2018.04.001

\section{Copyrights}

Copyright for this article is retained by the author(s), with first publication rights granted to the journal.

This is an open-access article distributed under the terms and conditions of the Creative Commons Attribution license (http://creativecommons.org/licenses/by/4.0/). 